\title{
Android Based Information System and SMS Gateway to Improve PMI Donors
}

\author{
Jatmiko Indriyanto ${ }^{1, *}$ Miftakhul Huda ${ }^{1}$ Qirom ${ }^{1}$
}

\author{
${ }^{1}$ Diploma Computer Engineering, Politenik Harapan Bersama, 52147, Indonesia \\ ${ }^{*}$ Corresponding author. Email: dewajat@gmail.com
}

\begin{abstract}
Researchers conducted research at PMI (Indonesian Red Cross) in Tegal City. After visiting PMI, the researchers found that PMI often held blood donor activities in various places. However, the efforts made are still unable to cover the blood needs that are needed each month. PMI has made efforts to send text messages manually to blood donors who have been donors before, but because there are thousands, so many are often missed. Therefore, an automatic sms system is needed, or often called an sms gateway based on existing donor databases, and data. that has been sent can be seen on android. The sequence of research methods, data collection, system analysis, problem identification, application design, application development and application implementation. With the existence of an Android-based information system and an SMS gateway, it certainly makes it very easy for PMI to raise blood donors, it can even increase the number of blood donors. With the Android-based information system and SMS gateway, it will certainly make it easier for PMI Tegal City to collect blood donors. This research succeeded in bringing in donors to donate blood regularly.
\end{abstract}

Keywords: PMI, Blood Donation, SMS Gateway.

\section{INTRODUCTION}

PMI (Indonesian Red Cross) is a humanitarian and social organization, whose daily task is to find blood donors and distribute them to those in need. PMI's routine activities include gathering blood donors in crowded places, providing medical assistance in natural disasters, as well as providing social and public health services. In accordance with PMI's main tasks,: aid preparedness and disaster management, training in first aid for volunteers, health and community welfare services, blood transfusion services.

The amount of demand for blood supply is currently very high, it is not proportional to the existing blood supply. Indonesia needs about 4 million bags of blood to meet people's needs in a year. However, blood donors in Indonesia still do not meet the ideal number, which is only $1.7 \%$ of the total population, below the ideal number of around 3\%. This shows that the amount of blood supply in Indonesia is still lacking (Hapsari \& Herdiana, 2013). PMI Tegal City also often lacks blood supply, according to the information I got after visiting there. With the Android-based information system and SMS gateway, it will certainly make it easier for PMI Tegal City to collect blood donors. Because the donor is contacted and reminded when it is time for the donor.
PMI officers are also facilitated by this new product, the officers know the number of donors that have been texted per day, via Android cellphones, including their blood type. A long and excessive introduction will make the reader stop reading. An introduction can be presented in the following structure.

At PMI Tegal City, every time there is a blood donation event, each donor is recorded the name, address, cellphone number, and blood type, date of the donor. This data is used by the PMI of Tegal City to contact the donor, to remind blood donors that can be done routinely every 3 months, usually via SMS. However, due to the large number of donors, there are hundreds of people, often PMI Tegal City officers forget to text or miss them. This can lead to a reduction in the number of donors in Tegal City. Based on these problems, the researchers came up with an idea for an automatic sms reminder model, with the sms gateway method, so that with the existing data, they could send SMS every few months to the donors. This study aims to raise blood donors more effectively and efficiently, so it is hoped that PMI will rarely lack blood stock. Blood need and availability and number of blood transfusion units by provinces in Indonesia is presented in Table 1. 
Table 1. Blood Need and Availability and Number of Blood Transfusion Units by Provinces in Indonesia (Ministry of Health of the Republic of Indonesia, 2014)

\begin{tabular}{|c|c|c|c|c|c|}
\hline \multirow[b]{2}{*}{ Provinsi } & \multicolumn{4}{|c|}{ Darah } & \multirow{2}{*}{$\begin{array}{l}\text { Jumlah } \\
\text { UTD }\end{array}$} \\
\hline & $\begin{array}{l}\text { Kebutuhan } \\
\text { (Kantong) }\end{array}$ & $\begin{array}{l}\text { Yang Ada } \\
\text { (Kantong) }\end{array}$ & $\begin{array}{l}\text { Kekurangan } \\
\text { (Kantong) }\end{array}$ & $\begin{array}{c}\% \\
\text { Kekurangan }\end{array}$ & \\
\hline Aceh & 93.437 & 36.274 & 57.163 & 61,18 & 4 \\
\hline Sumatera Utara & 267.825 & 43.280 & 224.545 & 83,84 & 7 \\
\hline Sumatera Barat & 100.706 & 42.579 & 58.127 & 57,72 & 3 \\
\hline Jambi & 66.598 & 13.307 & 53.291 & 80,02 & 1 \\
\hline Riau & 122.873 & 42.430 & 80.443 & 65,47 & 5 \\
\hline Sumatera Selatan & 157.149 & 60.691 & 96.458 & 61,38 & 4 \\
\hline Kep. Riau & 38.752 & 20.356 & 18.396 & 47,47 & 3 \\
\hline Kep. Bangka Belitung & 26.795 & 3.910 & 22.885 & 85,41 & 2 \\
\hline Bengkulu & 35.993 & 10.104 & 25.889 & 71,93 & 3 \\
\hline Lampung & 157.615 & 55.436 & 102.179 & 64,83 & 6 \\
\hline DKI Jakarta & 200.039 & 321.919 & -121.880 & $-60,93$ & 1 \\
\hline Banten & 230.460 & 73.718 & 156.742 & 68,01 & 6 \\
\hline Jawa Barat & 909.457 & 368.099 & 541.358 & 59,53 & 23 \\
\hline Jawa Tengah & 653.692 & 487.146 & 166.546 & 25,48 & 36 \\
\hline DI Yogjakarta & 71.202 & 55.694 & 15.508 & 21,78 & 5 \\
\hline Jawa Timur & 765.377 & 530.605 & 234.772 & 30,67 & 37 \\
\hline Bali & 82.794 & 53.254 & 29.540 & 35,68 & 7 \\
\hline Nusa Tenggara Barat & 93.033 & 6.191 & 86.842 & 93,35 & 4 \\
\hline Nusa Tenggara Timur & 99.436 & 13.209 & 86.227 & 86,72 & 4 \\
\hline Kalimantan Barat & 90.179 & 25.211 & 64.968 & 72,04 & 4 \\
\hline Kalimantan Tengah & 46.576 & 7.853 & 38.723 & 83,14 & 3 \\
\hline Kalimantan Selatan & 76.811 & 39.559 & 37.252 & 48,50 & 3 \\
\hline Kalimantan Timur & 67.638 & 56.605 & 11.033 & 16,31 & 10 \\
\hline Sulawesi Utara & 47.093 & 15.418 & 10.452 & 67,26 & 4 \\
\hline Gorontalo & 22.206 & 11.754 & 10.452 & 47,07 & 1 \\
\hline Sulawesi Tengah & 55.743 & 14.767 & 40.976 & 73,51 & 4 \\
\hline Sulawesi Barat & 25.041 & 1.087 & 23.954 & 95,66 & 1 \\
\hline Sulawesi Selatan & 166.103 & 46.092 & 120.011 & 72,25 & 6 \\
\hline Sulawesi Tenggara & 47.411 & 10.511 & 36.900 & 77,83 & 3 \\
\hline Maluku Utara & 22.298 & 3.742 & 18.556 & 83,22 & 1 \\
\hline Maluku & 33.259 & 6.201 & 27.058 & 81,36 & 1 \\
\hline Papua & 66.214 & 2.726 & 63.488 & 95,88 & 3 \\
\hline Papua Barat & 16.934 & 624 & 16.310 & 96,32 & 1 \\
\hline Indonesia & 4.956 .741 & 2.480 .352 & 2.455 .164 & 49,53 & 206 \\
\hline
\end{tabular}

\section{METHOD}

The research location is in PMI Tegal City, which is located at Jalan KS Tubun, Tegal City. When the research was conducted from March 2020 to June 2016. The number of respondents was 30 people, how to process the observation data using SPSS software. The data collection techniques used in this study are as follows: observation, interviews, documentation and literature.

The research sequence can be illustrated in the following figure:Very likely, a novelty from a study is in the method section, even though the topic is the same as previous studies. New methods that are simpler but have the same ability to answer research questions are superior so that they can be replicated or applied by subsequent researchers. In addition, if the equipment has accuracy tolerance in reading data such as thermocouple, transducer, air flow meter, etc., it must also be stated clearly and honestly in the method section.

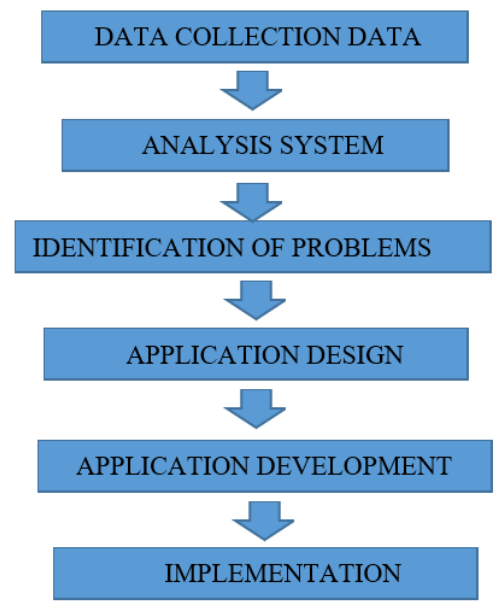

Figure 1 Research Sequence

The research method used, data collection, system analysis, problem identification, application design, application development and application implementation. The research is declared successful, if the application and tools have passed the blackbox test, and the results of the final questionnaire are entered into SPSS

\section{RESULT AND DISCUSSION}

\subsection{System planning}

The system design aims to provide a clear picture of the application for the notification of sending sms gateway to PMI Tegal. By utilizing the SMS Gateway that will be created. The design consists of Tiered Charts, Flowcharts, Data Flow Diagrams (DFD), Entity Relationship Diagrams (ERD), Database Design and Application Interface Design.

\subsubsection{Tiered Chart / Input Output Hierarchy (HIPO)}

Tiered chart is presented in Figure 1.

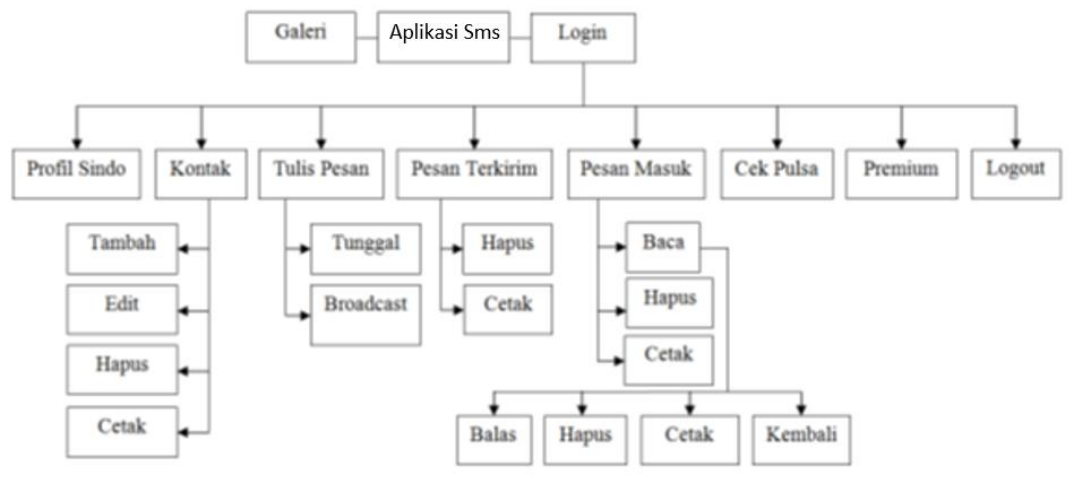

Figure 2 Tiered chart 


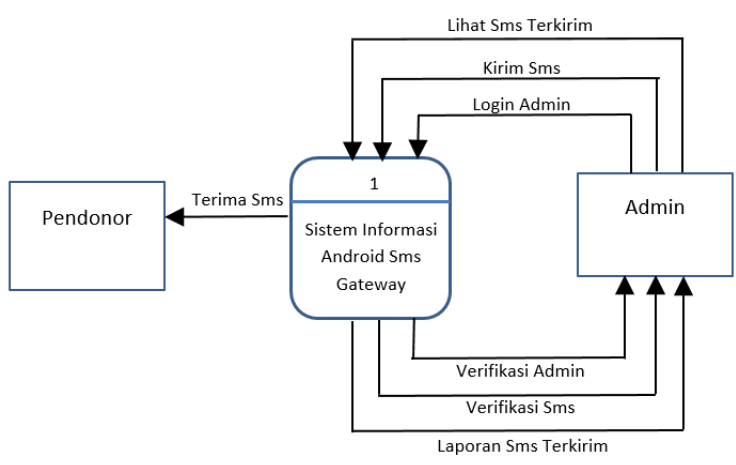

Figure 3 Context Diagram (DFD Level 0)

\subsubsection{Data Flow Diagram Level 1}

DFD level 1 of this library application consists of 3 processes, namely:

\subsubsection{Process Master Data}

This process handles the congregation data processing

\subsubsection{Process of Send SMS \& Receive SMS}

This process takes care of Sending Messages and Receiving Incoming Messages

\subsubsection{Print Process}

This process handles the Printing of Data Required for Company Interests

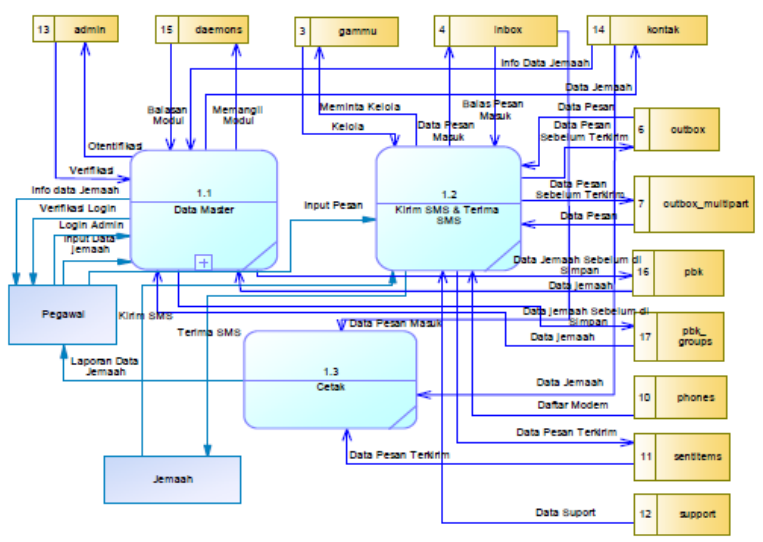

Figure 4 Relationship Diagram (ERD)

\subsubsection{Entity Relationship Diagram (ERD)}

This is an Entity Relationship Diagram Designing Announcement Information Application Using an SMS Gateway

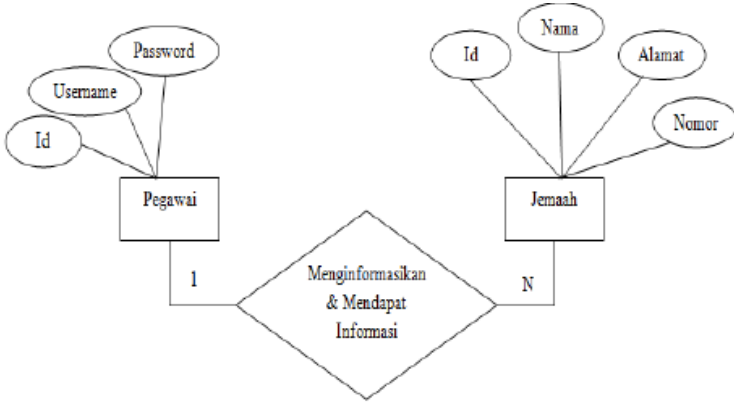

Figure 5 Entity Relationship Diagram

\subsection{System Creation}

\subsubsection{Splashscreen Menu page}

\section{Sistem Informasi dan SMS Gateway PMI Kota Tegal}

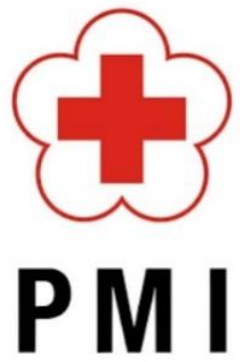

Figure 6 Initial view of the application

This is the first time that appears when a visitor / admin accesses the address of the SMS gateway application for PMI Kota Tegal, where only admin can enter the SMS Gateway menu by entering the specified Username and Password, while visitors can only access the Gallery menu and donor info. 


\subsubsection{Menu page of the donor sms gateway application}

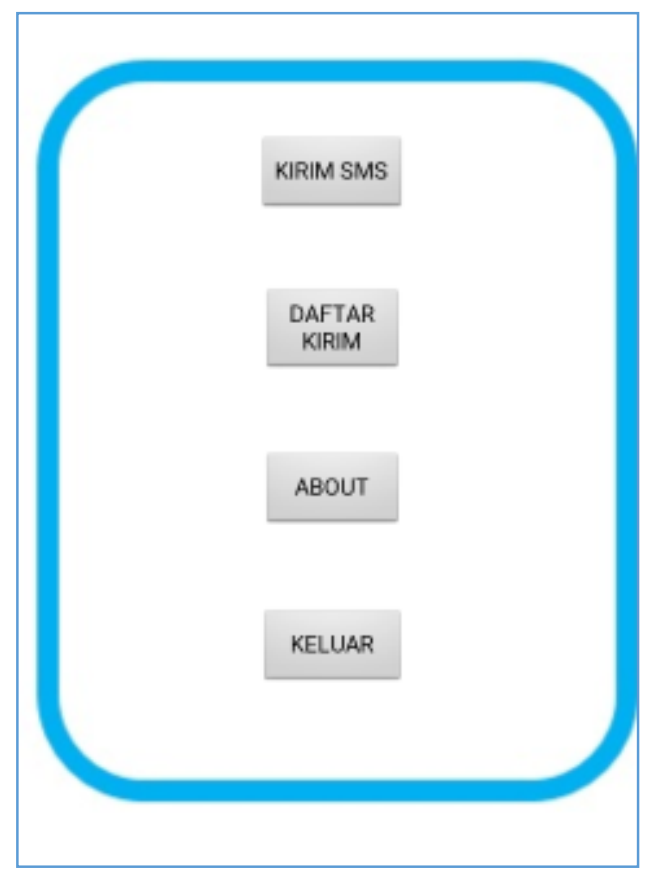

Figure 7 Application Menu Display

On the application Menu page there is a collection of menus to open the next display with different functions, on the Gallery Menu Page also visitors / admins can select the about application Menu Page and the Exit Menu Page.

\subsubsection{Send SMS Menu page}

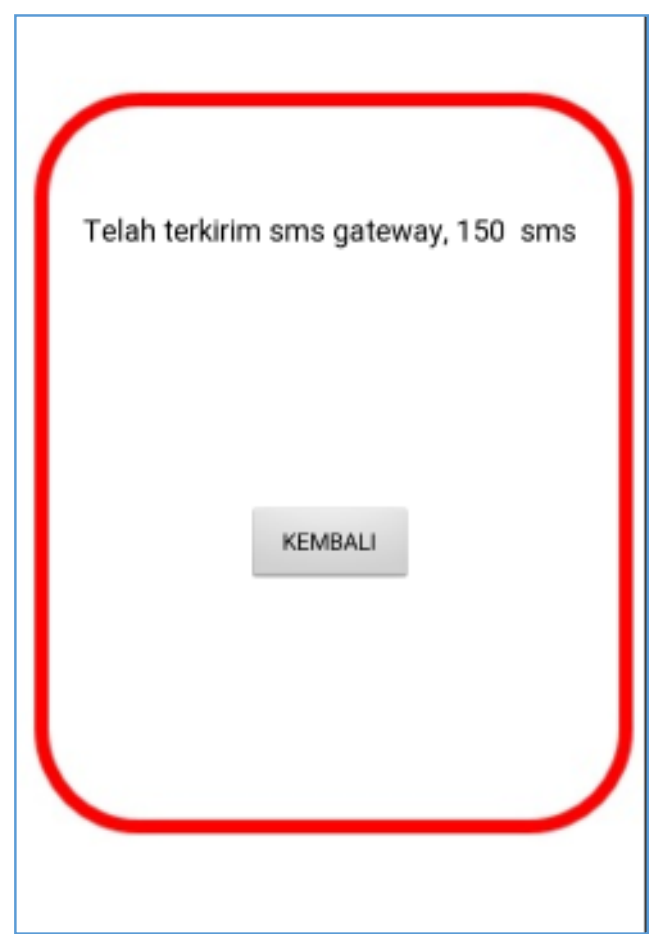

Figure 8 Send Sms Display
On the SMS sending page, there is information that Tegal City Pmi officers and blood donors need to know, on the Umrah Info Menu page visitors / admins can also select the Back Menu Page to return to the Main Menu.

\subsubsection{Sms Gateway Status Page}

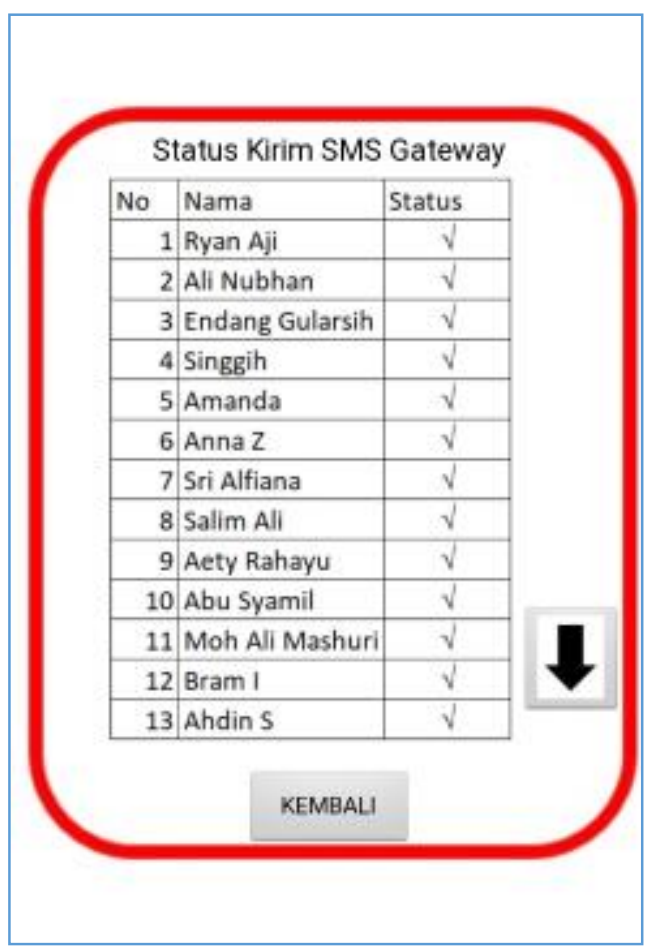

Figure 9 Display of SMS that has been sent

On the SMS gateway status page, there are donor data that the sms gateway has sent, the information can be used by pmi officers to validate the data that has been sent.

\subsubsection{Application about page}

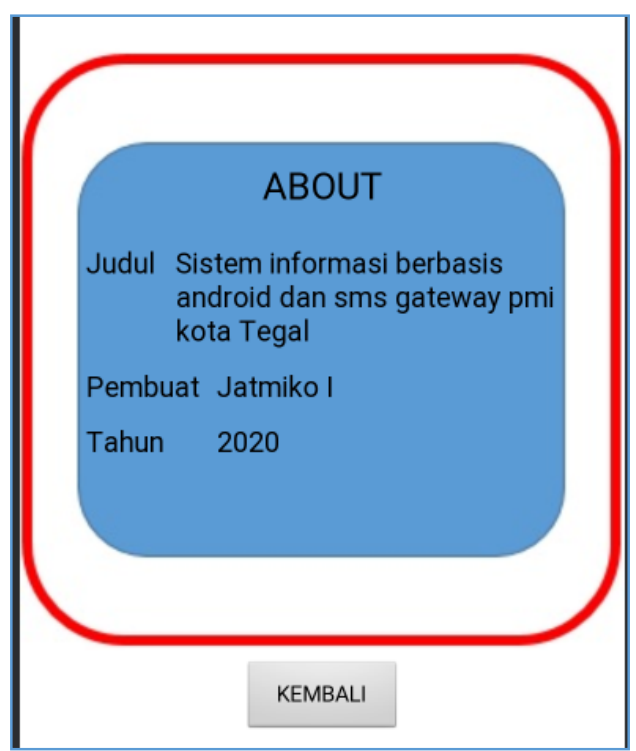

Figure 10 About the application 
On the about application page there is a description of the application maker, application title, year of manufacture and the menu back in the main menu.

\subsection{System Testing}

The android-based sms gateway application for PMI Tegal City has gone through the Black Box and WhiteBox tests and the results are:

\subsubsection{Black Box Testing}

All software functions have been running properly in accordance with defined functional requirements.

\subsubsection{White Box Testing}

No logic errors were found in the system and the system is functioning properly.

Based on the questionnaire divided among several donor members and Pmi Kota Tegal officers, the results are as follows:

Table 1. Questionnaire Results

\begin{tabular}{|c|c|c|c|c|c|}
\hline \multirow{2}{*}{ Number } & \multirow{2}{*}{ Name } & \multicolumn{2}{|c|}{ Application easy to use } & \multicolumn{2}{|c|}{$\begin{array}{l}\text { The application is according to its } \\
\text { function }\end{array}$} \\
\hline & & Yes & No & Yes & No \\
\hline 1 & Dwi Kukuh & $\mathrm{v}$ & & $\mathrm{v}$ & \\
\hline 2 & Satrio Anggoro & & $v$ & $v$ & \\
\hline 3 & Hendrawati & $\mathrm{v}$ & & $v$ & \\
\hline 4 & Wantoro & $\mathrm{v}$ & & & $v$ \\
\hline 5 & Zulfa S & $\mathrm{v}$ & & $v$ & \\
\hline 6 & Galuh Wahyu & & $v$ & $v$ & \\
\hline 7 & Budi Sulistio & v & & $v$ & \\
\hline 8 & Heri Santoso & $\mathrm{v}$ & & $v$ & \\
\hline 9 & Eko $S$ & $\mathrm{v}$ & & & v \\
\hline 10 & Sulistiyasni & & $v$ & $v$ & \\
\hline 11 & Anna Zarifah & $v$ & & $v$ & \\
\hline 12 & Probo Istika & $v$ & & $v$ & \\
\hline 13 & Diah Proborini & $v$ & & $\mathrm{v}$ & \\
\hline & & & & & \\
\hline
\end{tabular}

\section{CONCLUSION}

By using the SMS gateway application for Pmi Tegal City donors, using the SMS Gateway and Android application, it can make it easier for Tegal City officials to call back donors who are due to donate, so that the blood donor stock at PMI Tegal City is more stable and rarely empty.

\section{REFERENCES}

[1] Syaifudin dkk. 2013.Sistem Informasi Penggajian Karyawan Pada Toko Winscom Kabupaten
PacitanDengan Menggunakan PHP.ISSN: 2302-5700

[2] Umar Abdul A, Rinda Cahyana. 2015. Pengembangan Aplikasi Pengarsipan SuratDi Bagian Informatika Sekretariat DaerahKabupaten Garut Untuk Kemudahan Dalam PendisposisianSurat.ISSN : 2302-7339

[3] Wahana Komputer. 2013. Mobile Web Development With Adobe Dreamweaver CS6. Yogyakarta: C.V Andi Offset 
[4] Yudi Ardiansah, Anggit Dwi H. 2015. Perancangan Dan Pembuatan Aplikasi Ready ForBattle Futsal Berbasis Android. ISSN: 1411-3201

[5] Yuli Astuti, Erni Seniwati. 2013. Aplikasi Reservasi Ruangan Kelas. ISSN: 2089-9815

[6] Febrina Sari and Putri Lidya, Mobile Application Reminder of SPP Payment Schedule's and School Activities Information Based SMS Gateway, eISSN: 2289-8131 Vol. 9 No. 3-8

[7] P. Siagian dan E. Fernando, "Sistem Informasi Penerimaan Mahasiswa Baru Dengan SMS Gateway", vol. 6 no. 1, pp. 679-685, 2014.

[8] Tarigan, Daud Edison, Membangun SMS Gateway Berbasis Web dengan Codeigniter, Lokomedia, Yogyakarta, 2012.
[9] Randi V. Palit. 2015. Rancangan Sistem Informasi Keuangan Gereja Berbasis Web Di Jemaat GMIM Bukit Moria Malalayang. EJournal Teknik Elektro dan Komputer. Vol 4. No 7.

[10] Ribka Judita Veronica Pakasi. 2015. Aplikasi Monitoring KTP Kota Manado Menggunakan SMS Gateway. Teknik Elektro Fakultas Teknik Universitas Sam Ratulangi. Manado

[11] Tarigan, Daud Edison. 2012. Membangun SMS Gateway Berbasis Web dengan CodeIgneter. Lokomedia Yogyakarta

[12] Yaulie Deo. Y. Rindengan. 2016. Rancang Bangun Aplikasi Fasilitas Umum Berbasis Web Services. Ejournal Teknik Informatika. Teknik Informatika Universitas Sam Ratulangi Manado, Indonesia. 